\title{
An Unusual Child Abuse Case: Anthrax
}

\section{Contamination}

\section{Alışılmadık Bir Çocuk Istismarı Vakası: Şarbon Bulaştırılması}

\author{
Yasin Etli ${ }^{1^{*}}$, Ugur Demir $^{2}$, Mahmut Asirdizer $^{3}$ \\ ${ }^{1}$ Specialist of Forensic Medicine. Forensic Medicine Polyclinic, Medical Faculty Hospital of Selcuk University, Konya, Turkey \\ ${ }^{2}$ Researcher of Forensic Medicine. Department of Forensic Medicine, Medical Faculty of V an Yuzuncu Yil University, Van, Turkey \\ ${ }^{3}$ Professor of Forensic Medicine. Head of Department of Forensic Medicine, Medical Faculty of $V$ an Yuzuncu Yil University, V an- \\ Turkey
}

\begin{abstract}
Child abuse is defined as "any action, or action series or inactions to children under 18 years of age which cause to actual or potential harm to the child's health, survival, development or dignity in the context of a relationship of responsibility, trust or power". In this case report, we discussed a different type of child abuse, which includes deliberately contaminating anthrax by adults to a child. A 14 years-old boy was forced to contact with meat pieces and blood of a cow which infected with anthrax, causing him to get infected with anthrax. Medico-legal evaluation of our case was revealed that the child exposed to a different type of child abuse. In addition, it was observed that the lack of attention of the competent and responsible persons regarding the notification of infectious diseases caused hazardous situations.
\end{abstract}

Key Words: Child Abuse; Cutaneous Anthrax; Skin Lesions; Contamination; Legal Medicine.

\section{Introduction}

Child abuse is defined as "any action, or action series or inactions to children under 18 years of age which cause actual or potential harm to the child's health, survival, development or dignity in the context of a relationship of responsibility, trust or power". All types of physical or emotional ill-treatment, sexual abuse, neglect, negligence, and commercial or other exploitation are included in this description. $(1,2)$. Also, this definition covers the whole of conscious and unconscious behaviors of parents, other caregivers (e.g., teacher, coach, and clergy) or the societies and states that children are citizens (3).

\begin{abstract}
ÖZET
Çocuk istismarı, 18 yașın altındaki çocuklara yönelik, sorumluluk, güven veya güç ilişkisi bağlamında, çocuğun sağlığına, hayatta kalmasına, gelişimine veya onuruna zarar veren hareket, hareketler veya eylemsizlikler şeklindeki davranışlar olarak tanımlanmaktadır. Bu olgu sunumunda çocuğa yetişkinler tarafından kasıtlı bir şekilde Şarbon bulaştırılmasını içeren değişik tipte bir çocuk istismarı olgusunu tartışmak amaçlanmıştır. 14 yaşında erkek olguya yetişkinler tarafindan şarbon ile enfekte bir ineğin et parçalarına ve kanına temasa zorlanarak şarbon enfeksiyonu kapmasina neden olunmuştur. Yapılan adli tıbbi değerlendirme sonucunda olgumuzun değişik tipte bir çocuk istismarına maruz kaldığı ortaya çıkarılmıştır. Ayrıca, bulaşıcı hastalıkların bildirilmesinde yetkin ve sorumlu kişilerin yeterli dikkat ve özeni göstermemiş olmalarının son derece tehlikeli durumlara yol açabileceği de görülmüştür.
\end{abstract}

Anahtar Kelimeler: Çocuk İstismar1; Şarbon; Deri Bulguları; Bulaşıcı Hastalıklar; Adli Tıp

Child abuse is still an important worldwide problem today for children health despite the effective struggles in this regard. According to the data of ACF (The U.S. Department of Health \& Human Services Administration for Children and Families Administration on Children, Youth and Families Children's Bureau), it is estimated that 676,000 children (9.1 per 1,000 children) exposed to the child abuse in the United States and 1,750 children died as a result of these abuses (4). Types of child abuse differ from country to country, and according to gender, geographical region, and other factors (5). However, it is estimated that, every year, $4-16 \%$ of children are exposed to 
physical abuse and that one in every ten children is neglected or exposed to psychological abuse (6).

Anthrax is usually a disease of herbivores, and rarely infects humans by direct contact with the blood of infected animals or by inhalation of Bacillus anthracis spores (7). Although eradicated in many developed countries, this disease is still a significant problem in some regions of the world (e.g., Middle East, Africa, Central Asia, South America, and Haiti) (8). This infection is defined as an occupational illness of workers (e.g., veterinarians, industrial, and agricultural workers) who contact with infected animals $(7,8)$. In Turkey, there are articles that were written about 926 anthrax cases between 1990 and 2007. Among them, in 426 cases which were examined, it was reported $96.9 \%$ were cutaneous anthrax, 1.9\% were gastrointestinal anthrax and, $1.2 \%$ were anthrax meningitis. Most of the infection cases were from the central and eastern regions of Turkey and, $95.2 \%$ of cases were reported contact with materials contaminated with bacillus anthracis. (8).

Recently, there are 3709 articles in PubMed that contains "anthrax" in the title. Most of these articles concern clinical aspects of anthrax such as epidemiology, pathways, lesions in the body, clinical findings, and treatment. In this case report, in a different way from the previously reported in the literature, it was aimed to attract attention to the abuse in a child infected with cutaneous anthrax with a forensic medical point of view.

\section{Case Report}

A 14 years-old boy, who is a schoolboy and works as a shepherd out of school hours, saw his neighbor's cow was sick during grazing the cows with his friend on the event day. The owner of the cow and a butcher came to the place and, they slaughtered the sick cow there and began to tear it apart. During these events, the child has contact with cow blood and, a broken cow bone injured his forearm. After two hours from this event, the child fainted at his home. He was taken to the district hospital first. Medical treatment which includes antibiotics was started. After four days, the child was referred to the university hospital because the general condition of the patient has deteriorated. He was quarantined at the university hospital and had medical treatment for 14 days.

In the first medical examination of the case, swelling lesions were seen in his left forearm, and a soft tissue trauma was diagnosed. At the university hospital, the body temperature of the patient was defined to be $39^{\circ} \mathrm{C}$. In the laboratory examination, levels of CRP, blood fibrinogen DDimer, AST, and LDH were high, and other laboratory examinations were normal.

His doctor consulted him with Clinical Microbiology and Infectious Diseases Department. On the skin of flexor areas of his left forearm, there were several plaques which their middle part is necrotic, and the edge part is edematous and bullous. These lesions were not painful. In the palpation examination of the patient, there were multiple lymphadenopathies in the axillary regions. These lymphadenopathies were confirmed using the axillary ultrasonography; the size of the biggest lymphadenopathy was defined as 14 × $22 \mathrm{~mm}$. Clinical Microbiology and Infectious Diseases Department diagnosed cutaneous anthrax according to clinical aspect although the wound and blood cultures were negative. The clinical and radiological investigation revealed that there were not any signs of meningitis and anthrax lesions in other internal organs. The patient was medically treated, and he was discharged after 14 days from hospitalization. He was reported as a suspicious child abuse case to the prosecutor office by his doctor in charge. The child was sent to Forensic Medicine Polyclinic after 14 months from the event by the prosecutor office for preparing his medico-legal report about whether the presence or absence of findings of child abuse. In his examination in Forensic Medicine Polyclinic, it was seen that there were nine lesions on the patient's left forearm. Seven of them almost completely healed, and the two has not yet completed the healing process (Figure-1). The patient was re-consulted with the departments of Neurology, Dermatology, Chest Diseases, Clinical Microbiology, and Infectious Diseases. In these consultations, there was no sign of internal organ involvement.

In the statements taken in the police station, in brief; the child saw that the cow was sick and he called the owner of the cow. Upon this, the owner of the cow, with a butcher near him, came to the place where the incident happened. The butcher slaughtered the cow, but then he said that the cow might have died of infectious disease. For this reason, the butcher called and talked with a veterinarian on the telephone and asked for his opinion. The veterinarian said to keep the blood from the cow pouring into a cup and see if the blood clotted or not: If there is no clotting, it is 


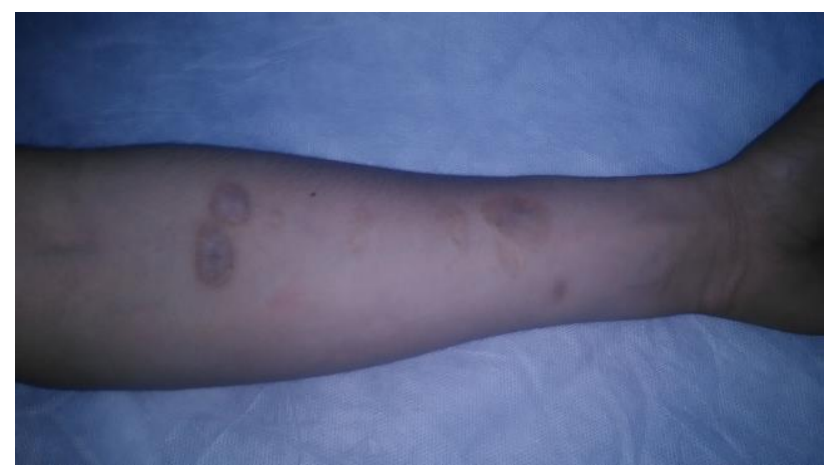

Fig.1. Nine lesions of patient's left forearm

possible that anthrax may be present and that they should be cautious. The butcher poured some blood in a bowl. After a while, he asked the child to put his hand in the blood and stir it. Then the butcher took a few organs. He told the owner of the cow to show these organs to the vet. However, it is understood that the owner did not show these organ parts to the veterinarian.

Meanwhile, the butcher forced the boy to carry some pieces of meat. During these events, the owner and the butcher were wearing gloves, but the child was not. While the child was carrying the meats, a scratched injury occurred on his left forearm with one of the cow's bone fragments. Then the child went home. His mother said that he fainted after he arrived at home. Thereupon his mother took him to the hospital, and he was hospitalized.

In the medico-legal evaluation, it was decided that the child had been abused by adults. Because the event confirmed by statements of the witness, suspect, and victim in the forensic investigation reports, His skin lesions were evaluated as "no curable by a simple medical intervention" and "not life-threatening because of the absence of internal organ involvement" in consistent with Turkish Penal Code.

\section{Discussion}

In Article 32 of Convention on the Rights of the Child, it was stated that "(1) States Parties recognize the right of the child to be protected from economic exploitation and from performing any work that is likely to be hazardous or to interfere with the child's education, or to be harmful to the child's health or physical, mental, spiritual, moral or social development (2). States Parties shall take legislative, administrative, social, and educational measures to ensure the implementation of the present article. To this end and having regard to the relevant provisions of other international instruments, States Parties shall in particular: (a) Provide for a minimum age or minimum ages for admission to employment; (b) Provide for appropriate regulation of the hours and conditions of employment; (c) Provide for appropriate penalties or other sanctions to ensure the effective enforcement of the present article" (9).

In Turkey, "child or young worker" concepts were defined in the "Regulation on the Operational Procedures and Principles of Children and Young Workers" (10). According to this regulation, a working person who completed 14 years of age but not completed 15 years of age and completed primary school is a child worker, a working person who completed 15 years of age but not completed 18 years of age is a young worker. In the context of these definitions, the presented case is in child worker status. However, "auxiliary work in sheep fattening" is defined as the work that young workers can work on but is not defined for child workers. In this context, the legal responsibilities for child abuse of the parents or official supervisors who have operated or allowed to operating the child in this work cannot be denied.

Also, it is more serious child abuse to make the child carry the meat pieces without gloves. When the whole case was considered, it is evident that adults forced the children who were not protected by gloves and who were unaware of the disease, to carry pieces of meat. At that time, they are aware of the condition and are protected by gloves. In the light of this information, the case was evaluated as "intentional or possible deliberate behavior" more than "the lack of attention and care" of according to the Turkish Penal Code (11). In the medico-legal evaluation of this case, causality was established with the witness, suspect, and victim statements and medical treatment reports, although wound and blood cultures were found to be negative. Also, 5 of 7 patients with cutaneous anthrax in the series of Doganay et al., had had negative Gram stains or blood cultures (7). Henderson et al. reported that antibiotic administration for $>24 \mathrm{~h}$ virtually precluded reproduction of pathogens from cultures of samples obtained from any site (12). The present case was applied four days after injury to the hospital, where the cultures were made.

According to the Turkish Penal Code, healthcare staff that encounters a case with a sign of a committed crime, have to report this case to the related authorities with a medico-legal report. In the conclusion of medico-legal reports, it should be clarified the severity degree of the injury and 
whether there are aggravating medical issues, as stated in the relevant article of the Turkish Penal Code. At this stage, "The Guide for Evaluation of the Injury Crimes Defined in Turkish Penal Code" is used. Since anthrax is a rare occurrence, especially in injury crimes, no information about anthrax was found in this guide. Therefore, the conclusion of our medico-legal report was evaluated with a committee of doctors. Committee concluded that this injury is "no curable by a simple medical intervention" and "not life threatening because of the absence of internal organ involvement". Although it is a rare condition, our conclusion may be a guide for healthcare personnel that will encounter this kind of cases. Additionally, we think that it would be useful to enter information about this kind of situations, where someone intentionally infect others with a microorganism which can cause serious infectious diseases, into "The Guide for Evaluation of the Injury Crimes Defined in Turkish Penal Code (Dated: June 2019)" which is already contains information about "rabid animal bite" (13).

According to the provisions of "Regulation on the Notification of Forced Animal Diseases (Dated: 22.01.2011; Numbered: 27823) of the Ministry of Agriculture and Rural Affairs; "Animal owners, animal keepers, veterinarians, village headmen, village guards, butchers, shepherds, ship captains, station or customs officers or administrators who encounter infectious animal disease or unexplained animal deaths, have to inform the competent authority about this case". Among the diseases that are required to be notified, anthrax has also been counted (14). In our case, it was seen that the owner of the cow and especially the butcher did not report the disease, which is against the regulations. In this case, it can be said that the meats consumed by the people. It is evident that this event is hazardous for public health, as the Gastrointestinal Anthrax, which is an anthrax form when it infects with food, has high mortality rates. When this situation is considered, it is seen that butchers and veterinarians need to be educated about the infectious disease notification and report. Anthrax contamination is an inevitable consequence of a lack of training and improvidence. Care should be taken in the places contamination is suspected; eating meat well-cooked can be useful in preventing contamination in such places.

Likewise, in the Directive on Notification and Reporting of Infectious Diseases (Dated: 24.02.2004; Numbered: 1534), it is stated that the health institutions that encounter anthrax case, which is listed among the Group-A Infectious Diseases, should report this situation to the Provincial Health Directorate (15). It was seen that the physician who evaluated our case at first, had difficulty in making the correct diagnosis and did not fulfill the task of reporting.

Children need attention and care from adults and especially physicians. Physicians do not only deal with the diagnosis and treatment of a patient; at the same time, they provide a range of support, including canalizing to the legal support. In the present case report, the medico-legal evaluation was revealed that the child exposed to different type of child abuse. In addition, it was observed that the lack of attention of the competent and responsible persons regarding the notification of infectious diseases caused extremely dangerous situations. Veterinarians, butchers, animal owners, parents, and doctors need training on this issue.

\section{References}

1. Child maltreatment (child abuse), World Health Organization (WHO), http://www.who.int/violence_injury_prevention /violence/child/en/ (ET: 24.07.2019).

2. Preventing Child Abuse \& Neglect, Centers for Disease Control and Prevention, https://www.cdc.gov/violenceprevention/childa buseandneglect/fastfact.html (ET: 24.07.2019).

3. Polat O. Adli Tip. Istanbul: Kardesler Yayıncilik; 2000.

4. Child Maltreatment 2016, U.S. Department of Health \& Human Services Administration for Children and Families Administration on Children, Youth and Families Children's Bureau, https://www.acf.hhs.gov/cb/resource/childmaltreatment-2016 (ET: 24.07.2019).

5. Yildirim Sari H, Ardahan E, Ozguven Oztornaci B. Systematic reviews about child abuse and neglect in last 10 years. TAF Preventive Medicine Bulletin. 2016; 15(6): 501-512.

6. Gilbert R, Widom CS, Browne K, Fergusson D, Webb E, Janson S. Burden and consequences of child maltreatment in high-income countries. Lancet. 2009; 373(9657): 68-81.

7. Doganay M, Metan G, Alp E. A review of cutaneous anthrax and its outcome. J Infect Public Health. 2010; 3(3): 98-105.

8. Doganay M, Metan G. Human anthrax in Turkey from 1990 to 2007. Vector Borne Zoonotic Dis. 2009; 9(2): 131-140.

9. Convention on the Rights of the Child, The Office of the High

Commissioner for Human Rights (United Nations Human Rights), http:/ / www.google.com.tr/url?sa $=$ t\&rct $=j \& q=\&$ 
esrc $=$ s\&source $=$ web\&cd $=1 \& \mathrm{cad}=$ rja\&uact $=8 \& \mathrm{v}$ ed=0ahUKEwjo8byuzt TZAhVK46QKHWUyC WUQFgg 5 MAA\&url=http $\% 3 \mathrm{~A} \% 2 \mathrm{~F} \% 2 \mathrm{Fwww}$.oh chr.org $\% 2$ FDocuments $\% 2$ FProfessionalInterest $\% 2$ Fcrc.pdf\&usg=AOvVaw10ERRCCUwT805JX 6Ysw0b5. (ET: 24.07.2019).

10. Çocuk ve Genç İşçilerin Çalıştırılma Usul ve Esasları Hakkında Yönetmelik, Mevzuat Bilgi Sistemi,

http://www.mevzuat.gov.tr/Metin.Aspx?Mevzua tKod $=7.5 .5457 \&$ MevzuatIliski $=0 \&$ sourceXmlSea rch $=\%$ C3 $\% 87$ ocuk $\% 20 v e \% 20$ Gen $\%$ C3 $\%$ A $7 \% 20$ $\% \mathrm{C} 4 \% \mathrm{~B} 0 \% \mathrm{C} 5 \% 9 \mathrm{~F} \% \mathrm{C} 3 \%$ A 7 ilerin $\% 20 \% \mathrm{C} 3 \% 87 \mathrm{a}$ $1 \% \mathrm{C} 4 \% \mathrm{~B} 1 \% \mathrm{C} 5 \% 9 \mathrm{Ft} \% \mathrm{C} 4 \% \mathrm{~B} 1 \mathrm{r} \% \mathrm{C} 4 \% \mathrm{~B} 1 \mathrm{lma} \% 20$ Usul $\% 20 \mathrm{ve} \% 20$ Esaslar $\% \mathrm{C} 4 \% \mathrm{~B} 1$

(ET: 24.07.2019).

11. Ozgenc I. Gerekçeli Türk Ceza Kanunu. Ankara: Seçkin Yayıncılık; 2004.
12. Henderson DA, Inglesby Jr TV, Borio L. Management of anthrax. Clinical Infection Disease 2002; 35(7): 851-858.

13. Türk Ceza Kanunu'nda Tanımlanan Yaralama Suçlarının Adli Tıp Açısından Değerlendirilmesi, Adli Tip Kurumu, https://www.atk.gov.tr/tckyaralama24-06-19.pdf (ET: 24.07.2019)

14. İhbarı Mecburi Hayvan Hastalıkları ve Bildirimine İlişkin Yönetmelik, Tarım ve Köyişleri Bakanlığı. http:/ /www.resmigazete.gov.tr/eskiler/2011/01/ 20110122-4.htm (ET: 24.07.2019).

15. Bulaşıcı Hastalıkların İhbarı ve Bildirim Sistemi Yönergesi, Sağllk Bakanlığı, https://www.saglik.gov.tr/TR,11238/bulasicihastaliklarin-ihbari-ve-bildirim-sistemiyonergesi.html (ET:24.07.2019). 